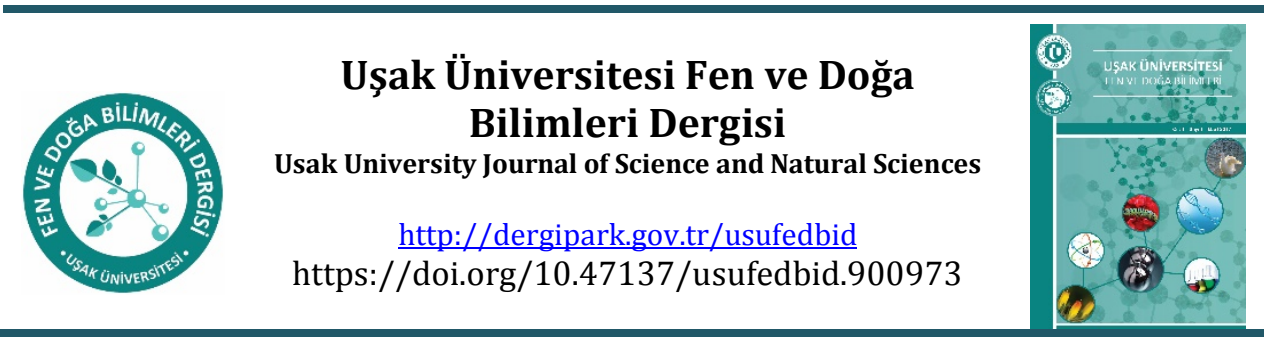

Araştırma makalesi

\title{
Bazı Çeltik Çeşitlerinde Toksik Düzeyde Demir İçerikli Tam Besin Çözeltisi Uygulamasının Taze Yapraklarda Peroksidaz ve Katalaz Aktiviteleri Üzerine Etkisi
}

\author{
Ahmet Korkmaz, Güney Akınoğlu* \\ Toprak Bilimi ve Bitki Besleme Bölümü, Ziraat Fakültesi, Ondokuz Mayıs Üniversitesi, Samsun, Türkiye
}

Geliş: 22 Mart 2021

Kabul: 4 Mayıs 2021 / Received: 22 March 2021

Accepted: 4 May 2021

\begin{abstract}
The aim of this study is to determine the effect of toxic level iron containing complete nutrient solution application on peroxidase and catalase activities in fresh leaves in some rice varieties. Iron in the form of iron sulphate is added to rice varieties grown in sand culture; Four different treatments were applied: I) 0 , II) $45 \mu \mathrm{M}$ Fe (sufficient Fe), III) $3.50 \mathrm{mM}$ Fe (toxic Fe), IV) $3.50 \mathrm{mM} \mathrm{Fe}$ (toxic Fe + sand media with bentonite) as four different treatments. The rate of decrease in peroxidase activity of iron application at toxic level was calculated as-7.18 \%, - $43.4 \%$ and - $4.16 \%$, respectively, in Biga incisi, Osmancik-97 and Hamzadere rice varieties. Also, it was calculated as $33.6 \%$ and $16.02 \%$, respectively in Ronaldo and Edirne rice varieties. According to these results, application of a nutrient solution containing toxic iron in Osmanclk rice variety decreased the peroxidase enzyme activity in fresh leaves more than other varieties. While Hamzadere and Edirne rice varieties are found to be the highest peroxidase enzyme activity, Osmanclk-97 and Ronaldo rice varieties have the lowest activity. The effect of Fe dose on catalase activity in fresh leaves was found to be statistically insignificant. Among the varieties grown at toxic iron level ( $3.50 \mathrm{mM} \mathrm{Fe}$ ), the variety with the highest catalase enzyme activity value in fresh leaves is the Hamzadere variety, whereas the lowest variety is seen to be Edirne rice variety.
\end{abstract}

Keywords: Rice variety, iron toxicity, peroxidase, catalase.

\section{Özet}

$\mathrm{Bu}$ çalışmanın amacı, bazı çeltik çeşitlerinde toksik düzeyde demir içerikli tam besin çözeltisi uygulamasının taze yapraklarda peroksidaz ve katalaz aktiviteleri üzerine etkisini belirlemektir. Kum kültüründe yetiştirilen çeltik çeşitlerine demir sülfat $\left(\mathrm{FeSO}_{4} \cdot 7 \mathrm{H}_{2} \mathrm{O}\right.$ ) formunda; I) 0 , II) $45 \mu \mathrm{M}$ Fe (yeterli Fe), III) $3.50 \mathrm{mM} \mathrm{Fe}$ (toksik Fe), IV) $3.50 \mathrm{mM} \mathrm{Fe}$ (toksik Fe + bentonitli ortam) şeklinde olmak üzere dört farklı muamele uygulanmıștır. Toksik düzeyde demir uygulamasının peroksidaz aktivitesinde sağladığı azalmanın oranı, Biga incisi çeşidinde -\% 7.18; Osmancık-97 çeşidinde -\% 43.4; Hamzadere çeşidinde -\% 4.16; Ronaldo çeşidinde -\% 33.6; Edirne çeşidinde -\% 16.02 olarak hesaplanmıştır. Bu sonuçlara göre Osmancık çeltik çeşidinde toksik düzeyde demir içeren besin çözeltisi uygulaması taze yaprakta peroksidaz enzim aktivitesini diğer çeşitlere göre daha fazla azaltımıştır. Peroksidaz enzim aktivitesi en yüksek çeşitlerin Hamzadere ve Edirne çeltik çeşitleri olduklarl; buna karşın, en düşük çeşidin ise Osmancık-97 ve Ronaldo çeşitleri olduğu tespit edilmiştir. Fe dozunun taze yaprakta katalaz aktivitesine etkisi istatistiksel olarak önemsiz bulunmuştur. Toksik demir düzeyinde (3.50 mM Fe) yetiştirilen çeşitler

\footnotetext{
*Corresponding author:

E-mail: guney_akinoglu@ymail.com

ORCID ID: 0000-0003-4624-2876
}

(C)2021 Usak University all rights reserved. 
arasında taze yaprakta katalaz enzim aktivite değeri en yüksek çeşidin Hamzadere çeşidi olduğu; buna karşın, en düşük çeşidin ise Edirne çeltik çeşidi olduğu görülmektedir.

Anahtar Kelimeler: Çeltik çeşidi, demir toksisitesi, peroksidaz, katalaz.

(C)2021 Usak University all rights reserved.

\section{Giriş}

Bitkilerin stres faktörlerine karşı olan toleransları farklıdır. Bunda bitkinin türü, stres faktörü, strese maruz kalma süresi ve strese maruz kalan doku veya organın yapısı etkilidir. Bitkilerin bu ağır metallere karşı hangi tepkiler verdiğini ve hangi savunma mekanizmaları geliştirdiğini belirlemek oldukça önemlidir [1].

Abiyotik stres şartları altında bitkilerde reaktif oksijen türleri (ROS) olarak adlandırılan oldukça toksik ve reaktif moleküller oluşmaktadır. Bu moleküller protein, lipid karbohidrat ve DNA'nın yapısını bozarak oksidatif stresin oluşmasına neden olmaktadır. $\mathrm{Bu}$ hasarın önlenmesine yönelik olarak bitkiler de antioksidant savunma sistemlerine sahiptir. Bu antioksidant sistemler enzimatik (süperoksit dismutaz, SOD; katalaz, CAT; askorbat peroksidaz, APX; glutatyon redüktaz, GR vb.) ve enzimatik olmayan (fenolik bileşikler, alkoloid, askorbik asit, glutatyon vb.) olmak üzere ikiye ayrılır [2].

Ağır metaller membran lipidlerinin de dahil olduğu biyomoleküllere hasar vererek oksidatif stresin oluşmasına neden olan hidrojen peroksit $\left(\mathrm{H}_{2} \mathrm{O}_{2}\right)$ gibi reaktif oksijen türlerinin (ROS) oluşumuna neden olmaktadır [3]. Biyotik ve abiyotik stres bitki hücrelerinde birçok karışık savunma mekanizmasını harekete geçirmektedir. Savunmada biyokimyasal mekanizmalarda birçok antioksidan molekül görev almaktadır. Bu moleküllerden biri de peroksidazdır. Peroksidazın $\mathrm{H}_{2} \mathrm{O}_{2}$ 'in yıkılmasında görev aldığının tahmin edilmesi [4] bitki savunma enzimleri arasında hücre yapısını güçlendiren savunma bariyerlerinin oluşumuna katkıda bulunan enzimlerin aktivitelerinin tespit edilmesi önemlidir.

Becana ve ark. (1998) serbest $\mathrm{Fe}^{+2}$ iyonunun, bitki hücreleri içerisinde Fenton reaksiyonu yoluyla tekli oksijen, süperoksit radikalleri $\left(\mathrm{O}^{-2}\right)$, hidrojen peroksit $\left(\mathrm{H}_{2} \mathrm{O}_{2}\right)$ ve hidroksil radikali ( $\mathrm{OH} \cdot$ ) dahil olmak üzere reaktif oksijen türlerinin (ROS) oluşumunu hızlandırdığını bildirmiş̧lerdir [5]. ROS'un, toksik olup; lipidlere, proteinlere ve nükleik asitlere verilen zararla doğrudan ilişkili olduğu araştırıcılar tarafından bildirilmiştir.

Tiryakioğlu ve ark. (2006) bitkilerin ROS'u uzaklaştırmak ve zararlı etkilerini azaltmak için birkaç koruyucu enzimatik ve enzimatik olmayan mekanizma geliştirdiğini rapor etmişlerdir [6]. CAT, peroksidazlar, askorbat peroksidaz, SOD ve glutatyon redüktaz gibi ROS temizleme enzimleri ile glutatyon, askorbat ve karotenoidler gibi birtakım antioksidanların bitkilerde ROS detoksifikasyonunu gerçekleștirdiği yine aynı araştırıcılar tarafından bildirilmiştir.

Farklı konsantrasyonlarda (100, 200 ve $300 \mu \mathrm{M}$ ) uygulanan ağır metaller (kadmiyum kurșun ve kadmiyum + kurșun) SOD ve katalaz enzim aktivitesinde azalıșlara neden olmuștur. SOD enzim aktivitesi, ağır metallerin kombine etkisinin (kadmiyum + kurșun) tek tek ağır metal uygulamasına göre katalaz enzim aktivitesi üzerinde daha fazla etkili olduğu bulunmuştur [7]. 
$\mathrm{Bu}$ çalışmanın amacı, bazı çeltik çeşitlerinde toksik düzeyde demir içerikli tam besin çözeltisi uygulamasının taze yapraklarda peroksidaz ve katalaz aktiviteleri üzerine etkisini belirlemektir.

\section{Materyal ve Yöntem}

Kum kültüründe sera şartlarında yetiştirilen çeltik çeşitleri Karadeniz Tarımsal Araştırma Enstitüsü'nden temin edilmiștir. Bu çeşitler: Biga incisi, Osmancık-97, Hamzadere, Ronaldo ve Edirne çeltik çeşitleridir.

\subsection{Deneme}

Çeltik tohumları \% 5.0'lık (v/v) sodyum hipoklorit çözeltisi içerisinde 15 dakika bekletilerek, tohumların sterilizasyonu sağlanmıştır. Daha sonra çeltik tohumları deiyonize su ile yıkanıp nemli bez torbalarda çimlendirildi. Çimlenen tohumlar, içerisinde perlit bulunan $40 \times 25 \times 5 \mathrm{~cm}$ boyutundaki beyaz plastik küvetlere aktarılarak 10 gün içinde çeltik fideleri haline gelmesi sağlandı. Çeltik fideleri $1 \mathrm{~kg}$ kuvars kumu dolu plastik saksılara $(12 \times 12 \mathrm{~cm})$ her saksıda 10 bitki olacak şekilde dikilmiştir. Çeltik çeşitlerine demir sülfat ( $\mathrm{FeSO}_{4} \cdot 7 \mathrm{H}_{2} \mathrm{O}$ ) formunda; I) 0 , II) $45 \mu \mathrm{M} \mathrm{Fe}$ (yeterli Fe), III) $3.50 \mathrm{mM} \mathrm{Fe}$ (toksik Fe), IV) $3.50 \mathrm{mM} \mathrm{Fe} \mathrm{(toksik} \mathrm{Fe+} \mathrm{bentonitli} \mathrm{ortam)} \mathrm{şeklinde} \mathrm{olmak} \mathrm{üzere} \mathrm{dört}$ farklı muamele uygulanmıştır. Denemede saksılardaki kum yüzeyinden itibaren $3 \mathrm{~cm}$ su katmanı olacak şekilde besin çözeltisi 5 farklı çeltik çeşidine eşit hacimlerde ilave edilmiştir. Bitki besin çözeltisinin pH'sı seyreltik $\mathrm{HCl}$ ya da $\mathrm{KOH}$ çözeltisi kullanılarak 5.5'e ayarlanmıştır. Deneme 50 gün sürmüștür. Denemede Zhang ve ark. (1998) tarafından bildirilen ve demir içermeyen aşağıdaki konsantrasyonlarda mutlak gerekli besin maddelerini içeren bitki besin çözeltisi kullanılmıştır [8].

$500 \mu \mathrm{M} \mathrm{NH}_{4} \mathrm{NO}_{3} ; 60 \mu \mathrm{M} \mathrm{NH}_{4} \mathrm{H}_{2} \mathrm{PO}_{4} ; 230 \mu \mathrm{M} \mathrm{K}_{2} \mathrm{SO}_{4} ; 210 \mu \mathrm{M} \mathrm{CaCl}_{2} ; 160 \mu \mathrm{M} \mathrm{MgSO}_{4} .7 \mathrm{H}_{2} \mathrm{O}$; $2.5 \mu \mathrm{M} \mathrm{MnCl}_{2} ; 0.75 \mu \mathrm{M}\left(\mathrm{NH}_{4}\right)_{6} \mathrm{Mo}_{7} \mathrm{O}_{24} ; 3.2 \mu \mathrm{M} \mathrm{H}_{3} \mathrm{BO}_{3} ; 0.1 \mu \mathrm{M} \mathrm{CuSO}_{4} ; 2.0 \mu \mathrm{M}$ $\mathrm{ZnSO}_{4} \cdot 7 \mathrm{H}_{2} \mathrm{O}$

\subsection{Bitkinin taze yaprağında bazı enzim aktivitelerinin belirlenmesi}

Taze yapraklarda peroksidaz (POD) ve katalaz (CAT) aktivitesini belirlemek amaciyla; demir noksanlığı, yeterli demir düzeyinde ve bentonitli ve bentonit ilavesiz toksik demir düzeylerinde yetiştirilen çeltik çeşitlerinden ayrı ayrı besin çözeltisi uygulamasından 3 gün sonra enzim analizleri için bitkilerden taze yaprak örnekleri alınmıştır. Hasat edilen çeltik bitkisi yaprakları sıvı azotla dondurularak, biyokimyasal analizlere kadar $-86^{\circ} \mathrm{C}$ 'de saklanmıştır. Bazı enzim analizleri için bitki ekstraktının hazırlanmasında ise aşağıdaki proses gerçekleşmiştir:

POD ve CAT enzimlerinin ekstraksiyonu için yaklaşık $0.5 \mathrm{~g}$ taze yaprak örneği sıvı azot içerisinde porselen havan yardımıyla ezilip toz haline getirildikten sonra, $\% 1.0(\mathrm{w} / \mathrm{v})$ polivinil polipirolidon (PVPP) ve $1.0 \mathrm{mM}$ EDTA içeren $0.05 \mathrm{M}$ sodyum fosfat tamponuyla (pH 7.8) içerisinde homojenize edilmiştir. Homojenize edilen örnekler 20 dakika süresince $20.000 \mathrm{x}$ g'de santrifüj edildikten sonra elde edilen süpernatantlar, enzim analizlerinde kullanılmıştır. Enzim aktivitelerinin belirleneceği örnekler, ölçüm yapılıncaya kadar $\pm 4{ }^{\circ} \mathrm{C}$ sıcaklıkta tutulmuştur.

Taze yaprak örneklerinde Katalaz (CAT) aktivitesi, Dhindsa vd, (1981b); Peroksidaz (POD) aktivitesi, Wakamatsu vd, (1993) tarafından bildirilen metotlara göre yapılmıştır $[9,10]$. 
Numune ölçümleri OMÜ Ziraat Fakültesi Tarımsal Biyoteknoloji Bölümü laboratuvarında Analytic Jena 40 model UV-Spektrofotometre cihazı kullanılarak yapılmıștır. Her aktivite tayininde ölçümler 3 kez tekrarlanmıștır.

\section{3. İstatistiksel Analizler}

Faktöriyel deneme deseni 5 x 4 olup, varyans analizi SPSS 17.0 paket programı ile yapılmıştır.

\section{Bulgular ve Tartışma}

\subsection{Toksik düzeyde demir içeren tam besin çözeltisi uygulamasının çeltik çeşitlerinde taze yaprakta peroksidaz aktivitesi üzerine etkisi}

Çeltik çeşitlerinde toksik düzeyde demir içerikli tam besin çözeltisi uygulamasının taze yaprakta peroksidaz aktivitesine etkisine ilişkin varyans analiz sonuçları Tablo 1'de verilmiştir.

Tablo 1. Çeltik çeşitlerinde toksik düzeyde demir içerikli tam besin çözeltisi uygulamasının taze yaprakta peroksidaz aktivitesine etkisine ilişkin varyans analiz sonuçları

\begin{tabular}{lcccccccc}
\hline & \multicolumn{7}{c}{ Varyasyon kaynakları } \\
\hline \multirow{2}{*}{ Özellik } & $\begin{array}{c}\text { Demir sülfat } \\
\text { dozu }\end{array}$ & & Çeşit & \multicolumn{1}{c}{$\begin{array}{c}\text { Demir sülfat dozu } \times \\
\text { çeşit } \\
\text { interaksiyonu }\end{array}$} & Hata \\
\cline { 2 - 9 } & SD & KO & SD & KO & SD & KO & SD & KO \\
\hline Peroksidaz(POD) & 3 & $0.239^{* *}$ & 4 & $0.095^{* *}$ & 12 & $0.024^{* *}$ & 40 & 0.001 \\
\hline
\end{tabular}

${ }^{* *} \mathrm{p}<0.01 ;{ }^{*} \mathrm{p}<0.05$ SD: Serbestlik derecesi; KO: Kareler ortalaması

Çeltik çeşitlerinde toksik düzeyde demir içerikli tam besin çözeltisi uygulamasının taze yaprakta peroksidaz aktivitesine etkisine ilişkin değerler Tablo 2'de verilmiştir.

Tablo 2. Çeltik çeşitlerinde toksik düzeyde demir içerikli tam besin çözeltisi uygulamasının taze yaprakta peroksidaz aktivitesine etkisi

\begin{tabular}{|c|c|c|c|c|c|}
\hline \multirow[b]{2}{*}{ Çeltik çeşidi } & \multicolumn{5}{|c|}{$\begin{array}{c}\text { Peroksidaz } \\
\text { Spesifik aktivite (EU / mg) }\end{array}$} \\
\hline & $\begin{array}{c}\text { Fe 0 } \\
\text { (Kontrol) }\end{array}$ & $45 \mu \mathrm{M} \mathrm{Fe}$ & $3.50 \mathrm{mM} \mathrm{Fe}$ & $\begin{array}{c}3.50 \mathrm{mM} \mathrm{Fe}+ \\
\% 10 \\
\text { Bentonit }\end{array}$ & Ortalama \\
\hline Biga incisi & $0.873 \mathrm{gh}$ & $0.836 \mathrm{~h}$ & $0.776 \mathrm{i}$ & $0.877 \mathrm{gh}$ & $0.83 \mathrm{D}$ \\
\hline Osmancik-97 & $0.768 \mathrm{i}$ & $1.021 \mathrm{~d}$ & $0.578 \mathrm{k}$ & $1.054 \mathrm{bcd}$ & $0.85 \mathrm{D}$ \\
\hline Hamzadere & $1.058 \mathrm{bcd}$ & $0.937 \mathrm{ef}$ & $0.898 \mathrm{fg}$ & $1.096 \mathrm{~b}$ & $0.99 \mathrm{~B}$ \\
\hline Ronaldo & $0.962 \mathrm{e}$ & $0.960 \mathrm{e}$ & $0.637 \mathrm{j}$ & $1.085 b$ & $0.90 \mathrm{C}$ \\
\hline Edirne & $1.030 \mathrm{~cd}$ & $1.067 \mathrm{bc}$ & $0.896 \mathrm{fg}$ & $1.183 a$ & $1.04 \mathrm{~A}$ \\
\hline Ortalama & $0.93 \mathrm{C}$ & $0.96 \mathrm{~B}$ & $0.75 \mathrm{D}$ & $1.05 \mathrm{~A}$ & \\
\hline
\end{tabular}

*Aynı harflerle gösterilen ortalamalar arasında \% 5 düzeyinde fark yoktur 
Tablo 1 ve 2'nin incelenmesinden anlaşılacağı üzere demir dozunun, çeşidin, demir dozu×çeşit interaksiyonunun taze yaprakta peroksidaz aktivitesine etkisi $p<0.01$ seviyesinde istatistiksel olarak önemli bulunmuștur. Yeterli düzeyde demir (45 $\mu \mathrm{M} \mathrm{Fe})$ içeren besin çözeltisi uygulaması, kontrole ( $\mathrm{Fe} 0)$ kıyasla taze yaprakta peroksidaz aktivitesini arttırmıș; fakat toksik düzeyde demir (3.50 mM Fe) içeren besin çözeltisi uygulaması bu enzim aktivitesini azaltmıștır. Buna karşın, bentonit ilaveli kum ortamına toksik düzeyde demir (3.50 mM Fe + \% 10 Bentonit) içeren demir sülfatlı besin çözeltisi uygulaması taze yaprakta peroksidaz aktivitesini arttırmıștır. Genel ortalamalar dikkate alındığında; taze yapraklarda belirlenen peroksidaz aktivite değerleri bakımından çeltik çeşitleri büyükten küçüğe doğru sırasıyla; Edirne > Hamzadere > Ronaldo > Osmancık-97 $>$ Biga incisi șeklinde sıralanmıștır (Tablo 2). Toksik konsantrasyonda demirli besin çözeltisi uygulaması sonucu bütün çeltik çeşitlerinde peroksidaz aktivitesi önemli derecede azalma göstermiştir.

Değişik konsatrasyonlarda demir içeren demir sülfatlı besin çözeltileri ile yetiştirilen çeltik çeşitlerinin taze yapraklarında belirlenen peroksidaz aktivite değerleri farklı bulunmuştur (Şekil 1).

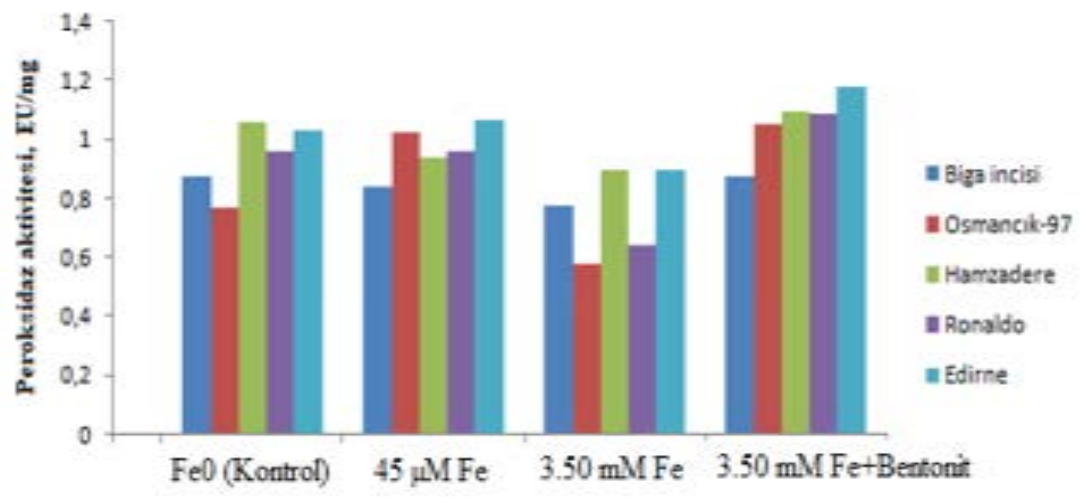

Şekil 1. Çeltik çeşitlerinde toksik düzeyde demir içerikli tam besin çözeltisi uygulamasının taze yaprakta peroksidaz enzim aktivitesine etkisi

Şekil 1'in incelenmesinden anlaşılacağı üzere toksik düzeyde demir uygulaması, kontrol ve yeterli demir düzeyi uygulamalarına kıyasla taze yaprakta peroksidaz enzim aktivitesini azaltmıştır. Yeterli demir düzeyindeki peroksidaz aktivitesine göre, toksik düzeyde demir uygulamasının peroksidaz aktivitesinde sağladığı azalmanın oranı, Biga incisi çeşidinde -\% 7.18; Osmancık-97 çeşidinde -\% 43.4; Hamzadere çeşidinde -\% 4.16; Ronaldo çeşidinde -\% 33.6; Edirne çeşidinde -\% 16.02 olarak hesaplanmıştır. Toksik düzeyde demir uygulamasıyla, yeterli demir düzeyine göre peroksidaz aktivitesinde en fazla azalma Osmancık-97 çeltik çeşidinde görülmüş; buna karşın, en az azalma ise Hamzadere ve Biga incisi çeltik çeşitlerinde görülmüştür. Toksik düzeyde demir sülfatlı besin çözeltisi ile yetiştirilen çeltik çeşitleri taze yapraklarda belirlenen peroksidaz aktiviteleri bakımından yüksek değerden düşük değere doğru sırasıyla; Edirne, Hamzadere, Biga incisi, Ronaldo, Osmancık-97 şeklinde sıralanmıștır. Buna göre, çeşitler arasında taze yaprakta peroksidaz aktivite değeri en yüksek çeşitlerin, Edirne ve Hamzadere çeltik çeşitleri oldukları; buna karşın, en düşük çeşidin Osmancık-97 olduğu, bununla birlikte Ronaldo çeltik çeşidinin de peroksidaz aktivitesinin Biga İncisi, Hamzadere ve Edirne çeltik çeşitlerinden daha düşük olduğu görülmüştür. Katalaz ve 
peroksidaz aktivitesi yüksek çeşitlerin demir toksisitesine dayanıklı olduğu bildirilmiştir $[11,12]$.

Bentonit ilaveli kum ortamına toksik düzeyde demir sülfatlı besin çözeltisi uygulaması bütün çeltik çeșitlerinde yaprakta peroksidaz aktivitesini, bentonitsiz kum ortamında yetiștirilen çeșitlerinkine göre arttırmıștır. $\mathrm{Bu}$ artıșın nedeninin, bentonitli kum ortamında çeltik bitkilerinin demir alımlarının baskılanmasıdan ileri geldiği düşünülmektedir.

Peroksidaz (POD), hidrojen atomlarını vermek eğiliminde olan bileşikler ile bu atomları alıcl durumunda olan hidrojen peroksit $\left(\mathrm{H}_{2} \mathrm{O}_{2}\right)$ bileşiği arasındaki reaksiyonu katalizleyen bir oksidoredüktazdır $[13,14]$. Peroksidazlar, hidroksilik veya peroksidatif aktiviteleri yoluyla, hücre bölmelerinde ROS'un hem üretimini hem de atılmasını düzenleyebilir [15]. Ek olarak, peroksidazlar, lignin biyosentezine doğrudan katılırlar [16]. Saikia ve Baruah [21], üç farklı çeltik çeşidini (Mahsuri, Ranjit, Siyal Sali) $\mathrm{FeSO}_{4} \cdot 7 \mathrm{H}_{2} \mathrm{O}$ formundaki dört farklı demir (kontrol, 100, 200 ve $300 \mathrm{mg} \mathrm{kg}^{-1} \mathrm{Fe}^{+2}$ ) dozu uygulanan toprak ortamında saksılarda yetiştirmişlerdir. Araştırma bulgularına göre; $100 \mathrm{mg} \mathrm{Fe} \mathrm{kg}^{-1}$ dozunda bütün çeşitlerde POD aktivitesinde bir artış görülmüştür. Diğer yandan, demir uygulamasının en yüksek dozunda (300 $\mathrm{mg} \mathrm{Fe}^{+2} \mathrm{~kg}^{-1}$ ) POD aktivitesinin Siyal Sali ve Ranjit çeltik çeşitlerinde arttığı; Mahsuri çeşidinde ise azalma eğilimi gösterdiği bildirilmiştir.

\subsection{Toksik düzeyde demir içeren tam besin çözeltisi uygulamasının çeltik çeşitlerinde taze yaprakta katalaz aktivitesi üzerine etkisi}

Çeltik çeşitlerinde toksik düzeyde demir içerikli tam besin çözeltisi uygulamasının taze yaprakta katalaz aktivitesine etkisine ilişkin varyans analiz sonuçları Tablo 3'te verilmiştir.

Tablo 3. Çeltik çeşitlerinde toksik düzeyde demir içerikli tam besin çözeltisi uygulamasının taze yaprakta katalaz aktivitesine etkisi

\begin{tabular}{|c|c|c|c|c|c|c|c|c|}
\hline \multirow{3}{*}{ Özellik } & \multicolumn{6}{|c|}{ Varyasyon kaynakları } & & \\
\hline & \multicolumn{2}{|c|}{$\begin{array}{c}\text { Demir sülfat } \\
\text { dozu }\end{array}$} & \multicolumn{2}{|r|}{ Çeşit } & \multicolumn{2}{|c|}{$\begin{array}{c}\text { Demir sülfat dozu } \times \\
\text { çeşit } \\
\text { interaksiyonu }\end{array}$} & \multicolumn{2}{|c|}{ Hata } \\
\hline & SD & KO & SD & KO & SD & KO & SD & KO \\
\hline Katalaz (CAT) & 3 & $5.03 \mathrm{E}-5$ & 4 & $9.512 \mathrm{E}-5^{*}$ & 12 & $0.001^{* *}$ & 40 & $2.45 E-5$ \\
\hline
\end{tabular}

Tablo 4. Çeltik çeşitlerinde toksik düzeyde demir içerikli tam besin çözeltisi uygulamasının taze yaprakta katalaz aktivitesine etkisi

\begin{tabular}{|c|c|c|c|c|c|}
\hline \multirow[b]{2}{*}{ Çeltik çeşidi } & \multicolumn{5}{|c|}{$\begin{array}{c}\text { Katalaz } \\
\text { Spesifik aktivite (EU / mg) }\end{array}$} \\
\hline & $\begin{array}{c}\text { Fe 0 } \\
\text { (Kontrol) }\end{array}$ & $45 \mu \mathrm{M} \mathrm{Fe}$ & $3.50 \mathrm{mM} F e$ & $\begin{array}{c}3.50 \mathrm{mM} \mathrm{Fe}+ \\
\% 10 \\
\text { Bentonit }\end{array}$ & Ortalama \\
\hline Biga incisi & 0.021 bcde & $0.022 \mathrm{bcde}$ & $0.027 \mathrm{abcd}$ & $0.028 \mathrm{abcd}$ & $0.0247 \mathrm{~A}$ \\
\hline Osmancık-97 & 0.022 bcde & $0.027 \mathrm{abcd}$ & $0.019 \mathrm{de}$ & $0.026 \mathrm{abcd}$ & $0.0234 \mathrm{~A}$ \\
\hline Hamzadere & $0.020 \mathrm{cde}$ & $0.016 \mathrm{ef}$ & $0.030 \mathrm{ab}$ & $0.009 \mathrm{f}$ & $0.0190 \mathrm{~B}$ \\
\hline
\end{tabular}




\begin{tabular}{lccccc}
$\begin{array}{l}\text { Ronaldo } \\
\text { Edirne }\end{array}$ & $\begin{array}{c}0.022 \mathrm{bcde} \\
0.024 \mathrm{bcde}\end{array}$ & $\begin{array}{c}0.030 \mathrm{ab} \\
0.032 \mathrm{a}\end{array}$ & $\begin{array}{c}0.026 \mathrm{abcd} \\
0.014 \mathrm{ef}\end{array}$ & $\begin{array}{c}0.028 \mathrm{abc} \\
0.029 \mathrm{ab}\end{array}$ & $\begin{array}{c}0.0266 \mathrm{~A} \\
0.0241 \mathrm{~A}\end{array}$ \\
\hline \multirow{2}{*}{ Ortalama } & 0.0213 & 0.0257 & 0.0233 & 0.0239 & \\
\hline
\end{tabular}

*Aynı harflerle gösterilen ortalamalar arasında \% 5 düzeyinde fark yoktur

Tablo 3 ve 4'ün incelenmesinden anlaşılacağı üzere çeşidin taze yaprakta katalaz aktivitesine etkisi $\mathrm{p}<0.05$ seviyesinde istatistiksel olarak önemli bulunmuştur. Ayrıca, Fe

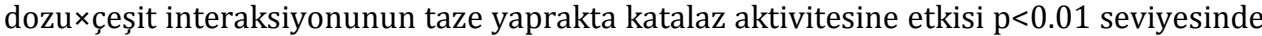
istatistiksel olarak önemli bulunmuştur. Fakat Fe dozunun taze yaprakta katalaz aktivitesine etkisi istatistiksel olarak önemsiz bulunmuștur. Genel ortalamalar dikkate alındığında; Biga incisi, Osmancık-97, Ronaldo ve Edirne çeltik çeşitleri taze yaprakta katalaz aktivite değerleri bakımından birbirlerine benzer ve yüksek bulunmuş; buna karşın, Hamzadere çeltik çeșidi ise taze yaprakta katalaz aktivite değeri bakımından en düşük çeltik çeșidi olarak tespit edilmiștir (Tablo 4). Toksik konsantrasyonda demirli besin çözeltisi uygulaması sonucu Biga İncisi ve Hamzadere çeltik çeşitlerinde katalaz aktivitesi artış gösterirken; diğer çeşitlerde azalma eğilimi göstermiştir.

Değişik konsantrasyonlarda demir içeren demir sülfatlı besin çözeltileri ile yetiştirilen çeltik çeşitlerinin taze yapraklarında belirlenen katalaz aktivite değerleri farklı bulunmuştur (Şekil 2).

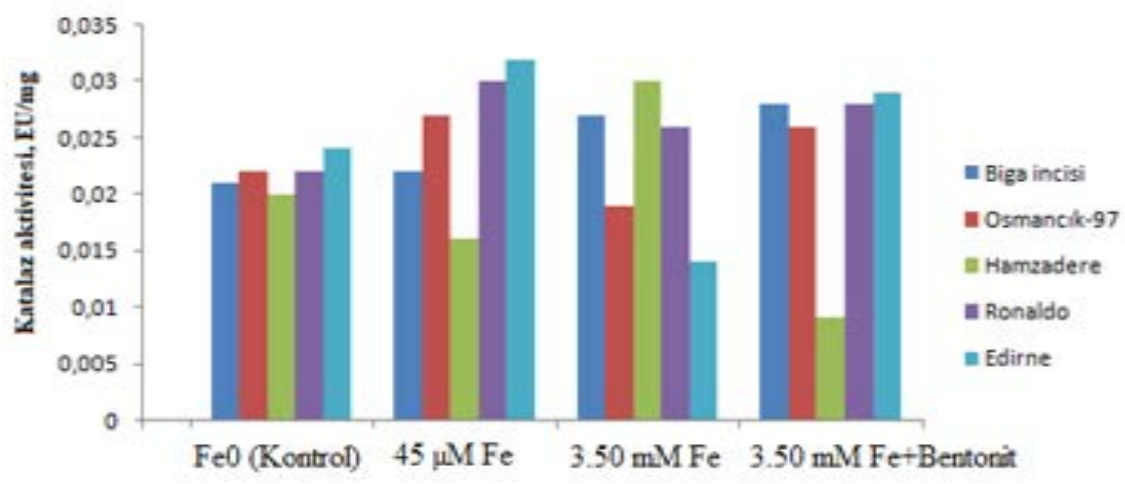

Şekil 2. Çeltik çeşitlerinde toksik düzeyde demir içerikli tam besin çözeltisi uygulamasının taze yaprakta katalaz enzim aktivitesine etkisi

Şekil 2'nin incelenmesinden anlaşılacağı üzere demir noksanlığı (Fe0) şartlarında yetiştirilen çeltik çeşitleri arasında taze yaprakta katalaz enzim aktivite değeri en yüksek çeșidin Edirne çeșidi olduğu; buna karșın, en düșük çeșidin ise Hamzadere çeltik çeșidi olduğu görülmektedir. Yeterli demir düzeyinde ( $45 \mu \mathrm{M} \mathrm{Fe})$ yetiştirilen çeşitler arasında taze yaprakta katalaz enzim aktivite değeri en yüksek çeşidin Edirne çeşidi olduğu; buna karşın, en düşük çeșidin ise Hamzadere çeltik çeșidi olduğu görülmektedir. Toksik demir düzeyinde ( $3.50 \mathrm{mM} \mathrm{Fe}$ ) yetiştirilen çeşitler arasında taze yaprakta katalaz enzim aktivite değeri en yüksek çeşidin Hamzadere çeşidi olduğu; buna karşın, en düşük çeşitlerin ise Edirne ve Osmancık-97 çeltik çeşitleri oldukları görülmektedir $[11,12]$.

Bentonit ilaveli kum ortamında toksik demir düzeyinde (3.50 mM Fe $+\% 10$ Bentonit) yetiştirilen çeşitler arasında taze yaprakta katalaz enzim aktivite değeri en yüksek çeşidin Edirne çeşidi olduğu; buna karşın, en düşük çeşidin ise Hamzadere çeltik çeşidi 
olduğu görülmektedir. Yeterli düzeyde demir içeren demir sülfatlı besin çözeltisi uygulanan çeșitlerdeki katalaz aktivitesine göre toksik düzeyde demir sülfatlı besin çözeltisi uygulanan Edirne, Osmancık-97 ve Ronaldo çeltik çeşitlerinde katalaz enzim aktivitesinde azalma görülmüş olup, bu azalma oranları sırasıyla -\% 56.25 , - $\% 28.6$ ve $-\%$ 13.33 olarak hesaplanmıștır. Buna karșın, toksik düzeyde demir uygulaması sonucu Hamzadere ve Biga incisi çeltik çeșitlerinde katalaz aktivitesi yeterli demir düzeyine göre artmış olup, bu artış oranları sırasıyla \% 87.5 ve \% 22.7 olarak hesaplanmıştır.

Toksik düzeyde ( $3.50 \mathrm{mM} \mathrm{Fe}$ ) demir sülfatlı besin çözeltisi uygulaması ile yetiştirilen çeltik çeșitleri taze yapraklarda katalaz aktivite değerleri bakımından yüksek değerden düşük değere doğru sırasıyla; Hamzadere, Biga incisi, Ronaldo, Osmanclk-97, Edirne șeklinde sıralanmıștır. Katalaz (CAT), stres koșulları altında olușan zararl $\mathrm{H}_{2} \mathrm{O}_{2}$ 'in, $\mathrm{H}_{2} \mathrm{O}$ ve $\mathrm{O}_{2}$ 'ya direkt olarak dönüșümünü sağlayarak hücreleri strese karşı korumada görevli en önemli enzimatik antioksidanlardan biridir [17]. Bitkiler, abiyotik stres nedeniyle oluşan reaktif oksijen türlerini antioksidan enzimler ve metabolitler aracılığıyla temizleyebilir [18, 19]. Katalaz (CAT), peroksidaz (POD), glutatyon redüktaz (GR), süperoksit dismutaz (SOD) ve askorbat peroksidaz (APX) gibi antioksidan enzimlerin genellikle bitkilerde metal stresi altında indüklendiği rapor edilmiștir [20,19]. Saikia ve Baruah [21] (2012), üç farklı çeltik çeşidini (Mahsuri, Ranjit, Siyal Sali) $\mathrm{FeSO}_{4} \cdot 7 \mathrm{H}_{2} \mathrm{O}$ formundaki dört farkl demir (kontrol, 100, 200 ve $300 \mathrm{mg} \mathrm{kg}^{-1} \mathrm{Fe}^{+2}$ ) dozu uygulanan toprak ortamında saksılarda yetiștirmișlerdir. Araștırma bulgularına göre; $100 \mathrm{mg} \mathrm{Fe} \mathrm{kg-1}$ dozunda Mahsuri çeltik çeşidinde CAT aktivitesinde bir düşüş görülmesine rağmen, daha yüksek demir dozunda bu çeșidin CAT aktivitesinde artış eğilimi gözlenmiștir. Öte yandan, demir uygulamasının en yüksek dozunda (300 $\mathrm{mg} \mathrm{Fe}^{+2} \mathrm{~kg}^{-1}$ ) CAT aktivitesinin Siyal Sali ve Ranjit çeltik çeşitlerinde azalma eğilimi gösterdiği bildirilmiştir. Gao ve ark. [22] tarafından yapılan bir araştırmada hidroponik kültürde aşırı demir stresine maruz bırakılarak yetiştirilen çeltik genotiplerinin CAT ve POD aktivitelerinin azaldığı ifade edilmiştir. Shahid ve ark. [23] demir toksisitesine dayanıklı çeltik çeşitlerinin, yaprak dokularında nispeten yüksek POD, CAT ve SOD aktiviteleri gösterdiğini bildirmiștir.

\section{Sonuçlar}

Yeterli düzeyde demir (45 $\mu \mathrm{M}$ Fe) içeren besin çözeltisi uygulaması, kontrole (Fe0) kıyasla taze yaprakta peroksidaz aktivitesini arttırmış; fakat toksik düzeyde demir (3.50 $\mathrm{mM}$ Fe) içeren besin çözeltisi uygulaması bu enzim aktivitesini azaltmıștır. Toksik düzeyde demir uygulamasının peroksidaz aktivitesinde sağladığı azalmanın oranı, Biga incisi çeşidinde -\% 7.18; Osmancık-97 çeşidinde -\% 43.4; Hamzadere çeşidinde -\% 4.16; Ronaldo çeşidinde -\% 33.6; Edirne çeșidinde -\% 16.02 olarak hesaplanmıștır. Toksik konsantrasyonda demirli besin çözeltisi uygulaması sonucu bütün çeltik çeşitlerinde peroksidaz aktivitesi önemli derecede azalma göstermiştir.

Toksik düzeyde demir sülfatlı besin çözeltisi ile yetiștirilen çeltik çeșitleri taze yapraklarda belirlenen peroksidaz aktiviteleri bakımından yüksek değerden düșük değere doğru sırasıyla; Edirne, Hamzadere, Biga incisi, Ronaldo, Osmancık-97 şeklinde sıralanmıștır. Buna göre, çeșitler arasında taze yaprakta peroksidaz aktivite değeri en yüksek çeșitlerin, Edirne ve Hamzadere çeltik çeșitleri oldukları; buna karşın, en düşük çeşidin Osmancık-97 çeltik çeşidi olduğu tespit edilmiştir.

Fe dozunun taze yaprakta katalaz aktivitesine etkisi istatistiksel olarak önemsiz bulunmuştur. Toksik demir düzeyinde $(3.50 \mathrm{mM} \mathrm{Fe})$ yetiștirilen çeșitler arasında taze yaprakta katalaz enzim aktivite değeri en yüksek çeşidin Hamzadere çeşidi olduğu; buna 
karşın, en düşük çeşidin ise Edirne çeltik çeşidi olduğu görülmektedir. Toksik konsantrasyonda demirli besin çözeltisi uygulaması sonucu Biga İncisi ve Hamzadere çeltik çeșitlerinde katalaz aktivitesi artış gösterirken; diğer çeșitlerde azalma eğilimi göstermiștir.

\section{Teșekkür}

Denemede materyal olarak kullanılan çeltik çeşitlerinin teminini sağlayan; T.C. Tarım ve Orman Bakanlığı Karadeniz Tarımsal Araştırma Enstitüsü Müdürlügüne teşekkür ederiz. Ayrıca, bu çalışmanın laboratuvar analizleri aşamasındaki katkılarından dolayı Ondokuz Mayıs Üniversitesi Ziraat Fakültesi Tarımsal Biyoteknoloji Bölümü asistanlarına çok teșekkür ederiz.

Bu çalışma, Güney Akınoğlu'nun doktora tezinden hazırlanmıştır.

\section{Çıkar Çatışması Beyanı}

Makale yazarları aralarında herhangi bir çıkar çatışması olmadığını beyan ederler.

\section{Kaynaklar}

1. Koç E, Üstün AS, Arıcı YK. Biber (Capsicum annuum L.) fidelerinde farklı çinko konsantrasyonlarının total protein, hidrojen peroksit içeriği ve peroksidaz aktivitesi üzerine etkisi. Artvin Çoruh Üniversitesi Orman Fakültesi Dergisi, 2012;13(2):205212.

2. Gill SS, Tuteja N. Reactive oxygen species and antioxidant machinery in abiotic stress tolerance in crop plants. Plant Physiology and Biochemistry, 2010;48: 909930.

3. Burzynski M, Klobus G. Changes of photosynthetic parameters in cucumber leaves under $\mathrm{Cu}, \mathrm{Cd}$ and Pb stress. Photosynthesis Research, 2004;42(4):505-510.

4. He CY, Hsiang T, Wolyn DJ. Induction of systemic disease resistance and pathogen defence responses in Asparagus officinalis inoculated with nonpathogenic strains of Fusarium oxysporum. Journal of Plant Pathology, 2002;51:225- 230.

5. Becana M, Moran JF. Iturbe-Ormaetxe I, Escuredo PR. Iron-dependent oxygen free radical generation in plants subjected to environmental stress: toxicity and antioxidant protection. Plant and Soil, 1998;201(1):137-147. doi: 10.1023/A:1004375732137

6. Tiryakioglu M, Eker S, Özkutlu F, Husted S, Çakmak I. Antioxidant defense system and cadmium uptake in barley genotypes differing in cadmium tolerance. Journal of Trace Elements in Medicine and Biology, 2006;20:181-189. doi:10.1016/j.jtemb.2005.12.004

7. Ak A, Yücel E. Ecotoxicological effects of heavy metal stress on antioxidant enzyme levels of Triticum aestivum cv. Alpu. Biological Diversity and Conservation, 2011;4/3:19-24.

8. Zhang X, Zhang F, Mao D. Effect of Fe plaque outside roots on nutrient uptake by rice (Oryza sativa L.): zinc uptake. Plant and Soil, 1998;202:33-39.

9. Dhindsa RS, Plumb-Dhindsa P, Throne TA. Leaf senescence correlated within creased levels of membrane permeability and lipid peroxidation and decreased levels of superoxide dismutase and catalase. Journal of Experimental Botany, 1981b:32:93-101.

10. Wakamatsu K, Takahama U. Changes in peroxidase activity and in peroxidase isozymes in carrot Callus. Physiologia Plantarum, 1993;88:167-171. 
11. Akınoğlu G. Çeltik bitkisinde demir toksisitesi, Birinci Basım, ISBN:978-625-770245-4, Ankara, Türkiye: Gece Kitaplığı; 2020. p. 148.

12. Korkmaz A, Akınoğlu G. Bitki beslemede toprak-kök etkileșimi, Birinci Basım, ISBN:978-625-7342-90-2, Ankara, Türkiye: Gece Kitaplığl, 2021. p. 400.

13. Nawar WW. Lipids in "food chemistry", O.R. Fennema (Ed). 3th Edition, New York: Marcel Dekker. 1996. p. 225-319.

14. Diplock A. Healty lifestyles nutrition and physical activity, Antioxidant nutrients, ILSI Europe Concise Monograph Series, 59. 1998.

15. Romero-Puertas MC, Corpas FJ, Rodriguez-Serrano M, Gomez M, del Río LA, Sandalio LM. Differential expression and regulation of antioxidative enzymes by $\mathrm{Cd}$ in pea plants. Journal of Plant Physiology, 2007;164:1346-1357.

16. Ranieri A, Castagna A, Baldan B, Soldatini GF. Iron deficiency differently affects peroxidase isoforms in sunflower. Journal of Experimental Botany, 2001;52(354):25-35.

17. Büyük İ, Soydam-Aydın S, Aras S. Bitkilerin stres koșullarına verdiği moleküler cevaplar. Türk Hijyen ve Deneysel Biyoloji Dergisi, 2012;69(2):97-110.

18. Dat JF, Vandenabeele S, Vranova E, Van Montagu M, Inze D, Van Breusegem F. (2000). Dual action of the active oxygen species during plant stress responses. Cellular and Molecular Life Science, 2000;57:779-795.

19. Kabir AH. Biochemical and molecular changes in rice seedlings (Oryza sativa L.) to cope with chromium stress. Plant Biology. 2016;18:710-719.

20. Cuypers A, Smeets K, Ruytinx J, Opdenakker K, Keunen E, Remans T. The cellular redox state as a modulator in cadmium and copper responses in Arabidopsis thaliana seedlings. Journal of Plant Physiology, 2011;168:309-316.

21. Saikia T, Baruah KK. 2012. Iron toxicity tolerance in rice (Oryza sativa) and its association with antioxidative enzyme activity. Journal of Crop Science, 2012;3(3):90-94

22. Gao PP, Zheng GH, Wu YH, Liu P. Effect of exogenous potassium on photosynthesis and antioxidant enzymes of rice under iron toxicity. Russian Journal of Plant Physiology, 2013;61:47-52.

23. Shahid M, Shukla AK, Nayak AK, Tripathi R, Meher J, Lal B, Gautam P. Root activity and antioxidant enzyme activities of rice cultivars under different iron toxicity mitigation options. Journal of the Indian Society of Soil Science, 2017;65(3): 341348. 